\title{
Nyestek (Martes foina Erxl.) táplálkozási szokásainak összehasonlító vizsgálata mezőgazdasági és urbánus környezetben
}

\author{
LANSZKI JÓZSEF
}

\begin{abstract}
LANSZKI J: Comparative study on feeding habits of the stone marten (Martes foina Erxl.) in rural and urban environments

Abstract: The investigations were carried out in a rural hilly area: forest, arable-land and pond mosaic habitat and a neighbouring village habitat in Somogy county. Stone martens living on different two habitats used similar food resources considerably. However the choosed prey differed significantly between the two populations in the point of view the weight, the zonation and the linkage to the human environment of the prey species.
\end{abstract}

\section{Bevezetés}

A nyest Martes foina (Erxleben, 1777) tipikus generalista ragadozó, ökológiai plaszticitása figyelemre méltó, széles az elterjedése. Napjainkban nemcsak természetes, vagy természeteshez közeli élőhelyeken, hanem különböző emberi településeken: falvaktól a nagyvárosokig is megtalálható. A ragadozók, így a nyestek territóriumának kiterjedését lényegesen befolyásolja a rendelkezésre álló táplálék mennyisége. Egyes vizsgálatok szerint az emberi településen kívül élő nyestek territóriuma 350-400 ha (SERAFINI és LOVARI, 1993), a hímek kétszer nagyobb területet birtokolnak, mint a nőstények (SEKNACK 1990, Posillico et al. 1995), az emberi településen élő nyestek territóriuma lényegesen kisebb. A nyári párosodási időszakban gyakoribbá válik a territórium birtoklását jelző ürülékek (és vizelet) tereptárgyakon, pl. köveken, fúcsomón történő elhelyezés gyakorisága (SEILER et al. 1994), ekkor a nyestek nappal is sokat mozognak (PosILLICo et al. 1995). A vizuális és szagjelek elsősorban az azonos ivar távoltartását szolgálják, de az aktuális szaporodásbiológiai állapotot is jelzik (MACDONALD 1980).

Éjszakai, rejtőzködő életmódja miatt a városok, falvak lakossága leginkább csak akkor szerez tudomást a nyestek jelenlétéról, amikor valamilyen kártételük merül fel. Ilyen lehet például a baromfiállomány megdézsmálása, a tetổterek hőszigetelő anyagának megbontása, az autók kábeleinek és egyéb műanyag alapanyagú tartozékok megrágása. Sok esetben azonban - tévesen - a rágcsálók okozta kárt is a rovására írják. Hihetetlen tájékozatlanság tapasztalható a velük szembeni (vértelen) védekezés terén is, és itt nemcsak a lakóházak tulajdonosai, hanem akár a patinás luxusszállodák, nagyüzemek védelmi rendszere (vagy inkább hiánya) is említhető. Urbanizálódott ragadozóról van szó, mely alkalmazkodott az emberi környezet nyújtotta előnyökhöz, eközben éli a vadon élő fajtársakra jellemző természetes életét, azaz zsákmányol.

Az emberi településeken kívül: hegyvidéki, mezőgazdasági és erdei élőhelyen élő nyestek táplálék-összetételét számos tanulmányban elemezték (pl. Dánia: RASMUSSEN és MadSEn 1985, Olaszország: Lucherini és CREMA 1993, SerafinI és Lovari 1993, Bertolino és Dore 1995, Brangi 1995, Martinoli és Preatoni 1995, Pedrini et al. 1995, Posillico et al. 1995, PANDOLFI et al. 1996, Franciaország: Lode 1994, Svájc: 
Tester 1986, Spanyolország: DeliBes 1978, Lengyelország: GoszCZynsKi 1986, Magyarország: LANSZKI et al. 1999). Annak ellenére, hogy a nyest gyakori (közönséges) faj, az emberi településeken előforduló populációk életmódja kevésbé kutatott (pl. Dánia: RASMUSSEN és MADSEN 1985, Olaszország: LuCHERINI és CREMA 1993, Svájc: Tester 1986, Cseh Köztársaság: Holisová és OBrtel 1982, Belorusszia: Sidorovich 1997, Magyarország: LANSZKi 1992, ТóTH-AрÁTHY 1998). A fenti, eltérő földrajzi szélességen, különböző típusú élőhelyeken végzett táplálék-összetétel vizsgálatok azt jelzik, hogy az urbánus és a „természetes” körülmények között élő nyestek időszakosan ugyan, de hasonló táplálékforrásokat is hasznosíthatnak. Ez előre vetíti azt a feltételezést, hogy előfordulási helyük eszerinti besorolásuk legfeljebb általánosságban lehet érvényes. Adott emberi településen belül és azon kívül élő nyest populációk táplálkozásökológiai összehasonlítását eddig ritkán vizsgálták (RASMUSSEN és MADSEN 1985, TESTER 1986).

A vizsgálatot egy dombvidéki tipikus mezőgazdaságilag művelt erdő-szántó-halastó mozaikos élőhelyen, valamint a közelében található kis falu nyestjeinek táplálék-analízise alapján végeztem. A kutatás fó célja a jellemzően mezőgazdasági és az urbánus nyestek közötti táplálkozási kapcsolatok vizsgálata az alábbiak alapján:

1) meghatározni az éves táplálék-összetételt, ezáltal következtetni a táplálkozási szokásokra,

2) meghatározni a két nyestpopuláció táplálkozási niche-átfedését, a kompetíció mértékét,

3) tesztelni a niche szegregálódás lehetséges módjait a préda fajok a) súlya, b) jellemző élőhelye és c) jellemző előfordulása (kötődése) alapján.

\section{Vizsgálati terület és módszerek}

A vizsgálat a fonói halastó körzetében, valamint Fonó községben zajlott. A fonói halastó és körzete Dél-nyugat Magyarországon (É $46^{\circ} 22^{\prime}, \mathrm{K} 17^{\circ} 55^{\prime}$ ) helyezkedik el. A tavat tápláló patak a Kapos folyó vízgyüjtőjéhez tartozik. Erre a vidékre alapvetően szántóföldi mezőgazdasági művelés jellemző. A terület növényzete a Dél- Dunántúli flóravidék külső-somogyi flórajárásához tartozik. A tó nyugati partján, nagyobbrészt egészen a tó partvonaláig cseres-tölgyes erdő (Quercetum petraeae-cerris) húzódik. Az erdő kora kb. 60 év, kiterjedése 70 ha, szántóval szabdalt. A tó északi oldalán kis kiterjedésű rét és bokorfüzes (Salicetum triandrae-purpurea), valamint magassásos (Caricetum acutiformis-ripariae) és nádas (Scirpo-Phragmitetum) teszi változatossá a növényzetet. A halastó keleti oldalán nagy kiterjedésű szántó, délen nyílt legelő, valamint fás legelő (Betula pendula, Robinia pseudo-acacia) húzódik. A felsorolt élőhelyeken történt a halastó körzetében („külterületen”) élő nyestek ürülékgyüjtése. A halastótól délkeleti irányban található Fonó község gyümölcsös kertekkel. A falu szélén állt a malom épülete, melynek egyik emberi mozgástól mentes szárnyának padlásterében végeztem a „,belterületi” minták gyüjtését.

A nyest táplálék-összetételének meghatározása hullaték analízissel történt. Ehhez a halastó körzetében a hullatékok gyüjtése kéthetenkénti gyakorisággal, standard útvonal (kb. 4,2 km) bejárásával zajlott. Az 1991 decembere és 1997 novembere közötti 6 év alatt feldolgozott mintaszám 572 (LANSZKI és KÖRMENDI 1999, LANSZKI et al. 1998, 1999). A malomból a mintagyüjtés egy alkalommal, 1998-ban történt. Az összegyült minták $(\mathrm{n}=151)$ feltételezhetően több évből származtak, évszakonkénti feldolgozást nem, csak éves értékelést tettek lehetővé.

A táplálék taxonok meghatározása az emlősöknél koponyacsontok, fogazat és szőr- 
morfológia (SCHMidT 1967, DeBrot et al. 1982, GöRNER és HaCKETHAL 1987, UjHelYi 1989, TEERINK 1991, saját referencia gyüjtemény), a madaraknál toll és koponyacsontok (BROWN et al. 1993, saját referencia gyüjtemény), a hüllőknél pikkelyek, csontok (DELY 1983), a kétéltüeknél csontok (PAUNOVIC 1990), a gerincteleneknél kültakaró (pl. MóczÁR 1969) alapján történt.

A táplálék-összetételt és a táplálkozási niche-átfedést a hullatékokban előforduló táplálékalkotók relatív előfordulási gyakorisága alapján számítottam ki. A táplálékalkotók kategóriánkénti relatív gyakoriságának a kifejezése a minimális egyedszám alapján történt. A belterületen gyüjtött minták feldolgozásakor a relatív előfordulási gyakoriság mellett a fogyasztott táplálék biomassza szerinti összetételét is meghatároztam. A nedves technikával előkészített ( $0,5 \mathrm{~mm}$-es lyukbőségű szitán átmosott), majd szárított táplálékmaradványok súlyát $0,01 \mathrm{~g}$ pontossággal lemértem. Az egyes taxon maradványok súlyát JEDRZEJEWSKA és JEDRZEJEWSKI (1998) által, nyestre vonatkozóan összefoglalt faktorszámokkal szoroztam. Ezek az alábbiak: rovarevők, denevérek, egyéb kisemlősök, valamint mókus és menyét 23; közepes testü emlősök (pl. mezeinyúl, házinyúl) 50; vaddisznó 118; szarvasfélék 15; nagytestü háziállatok (dög) 118; madarak 35; hüllők és kétéltűek 18; puhatestűek és egyéb gerinctelenek 5; és növények 14.

A táplálkozási niche számításnál alkalmazott 10 kategória: 1 - pocokfélék; 2 - egérfélék; 3 - egyéb rágcsálók (pelék és meghatározhatatlan rágcsálók) és mezeinyúl; 4 - rovarevők és denevérek; 5 - ragadozó emlősök és elhullott állatok (csülkös vad); 6 - háziállatok; 7 - madarak; 8 - egyéb gerincesek (hüllők, kétéltűek és halak); 9 - gerinctelenek (ízeltlábúak és puhatestűek) és 10 - növények. A nem táplálékként felvett (általában emészthetetlen) anyag, valamint a nyestek tisztálkodása során lenyelt (1-5 db) szőrszál nem szerepel a tápláléklistán.

A táplálkozási niche-szélességet LEvins-index alapján számítottam: $\mathrm{B}=1 / \Sigma$ pi2 , ahol pi $=$ adott taxon relatív gyakorisága. A niche-átfedés számítása Renkonen-index alkalmazásával történt [Pjk = 1-0,5(n(minimum pij, pik)100], ahol Pjk = százalékos átfedés a két élőhelyen ("j" és "k") előforduló nyest között; pij és pik = az i-edik táplálék taxon (forrás) részesedése a "j” és "k" élőhelyen élő nyestek táplálékában (a minimum azt jel$\mathrm{zi}$, hogy a kisebb értéket kell figyelembe venni), $\mathrm{n}=$ a táplálék taxonok (10 kategória) száma (KREBS 1989). A Fonó kül- és belterületén élő nyestek éves táplálék-összetételének eloszlásvizsgálatára $\chi^{2}$-tesztet alkalmaztam. A préda fajok listája a jellemző tulajdonságok szerint az 1. táblázatban található, a súly CLEVENGER (1993), a jellemző előfordulási szint alapján végzett besorolásnál GITTLEMAN (1985) munkáját vettem figyelembe. Az adatfeldolgozás SPSS 7.5 (GREEN et al. 1997) statisztikai programmal történt.

\section{Eredmények és értékelésük}

\section{Táplálkozási niche, táplálék-összetétel}

A Fonói halastó körzetében, valamint a településen élő nyestek közötti táplálkozási niche-átfedés nagymértékü $(78,5 \%)$ volt. A két nyestpopuláció táplálék-összetétele azonban taxonómiai szempontból szignifikánsan különbözött $\chi^{2}=139,28, \mathrm{df}=9$, $\mathrm{p}<0,001)$.

A mezőgazdasági környezetben élő nyestek zsákmányai között a kisemlősök (29,9\%) voltak a legjelentősebbek, míg az urbánus nyesteknél ezek szerepe lényegesen kisebb volt $(15,5 \%)$ (1. táblázat). A kisemlősök közül a tó körzetében élő nyesteknél a pocokfélék (elsősorban a mezei pocok), míg a lakott területen élőknél az egérfélék (elsősorban 
a házi egér) voltak a legfontosabbak. A tó körzetében élő nyest kisemlős tápláléka változatosabb volt, pl. denevért, vakondot, mókust, mogyorós pelét és pézsmapockot is fogyasztott. A mezeinyúl, mint táplálék faj előfordulása elenyészően alacsony $(0,3 \%)$ volt. Az urbánus nyestek táplálékában jelentős volt a házi egér (B\%: 12,3) és előfordult vándorpatkány fogyasztás. Az emberi településhez kötődő fajokon kívül előfordultak egyéb, jellemzően vadon élő kisemlősök is, pl. vízipocok, erdei pocok.

A halastó körzetében élő nyestek táplálékban előforduló borz és házimacska (1. táblázat) nagy valószínűséggel dögfogyasztásból származhatott, ugyanúgy, mint a vaddisznó és a szarvasfélék is. Ragadozók és csülkös vad a településen élő nyestek táplálékában nem szerepelt.

Mindkét nyest populáció egyedei fogyasztottak háziállatot, azonban lényegesen eltérő arányban (1. táblázat). A halastó nyugati oldalán húzódó erdőben, odvas fákban fészkelő nyestek táplálékában télen és nyáron volt számottevő a háziállatok előfordulása (1. ábra), éves viszonylatban 4,2\%-ot tettek ki. Az urbánus nyestek táplálékát biomassza számítás szerint ötödrészben háziállatok, ezek közül is elsősorban különböző baromfi fajok és tojás képezték.

A mezőgazdasági környezetben élő nyestek felényi madarat fogyasztottak, mint a lakott területen élő fajtársaik (1. táblázat). Az urbánus nyestek biomassza számítás szerinti domináns táplálékát madarak alkották, melyek közül a házi veréb volt a legfontosabb faj. Fácán csak a halastó körzetében élő nyestek táplálékában szerepelt, azonban ezeknél is a kistestü énekesmadarak voltak a fontosabbak.

Vizes élőhelyekhez kötődő gerincesek (hüllők, kétéltűek és halak) csak a halastó körzetében élő nyestek táplálékában szerepeltek (1. táblázat). Alacsony előfordulási ará-

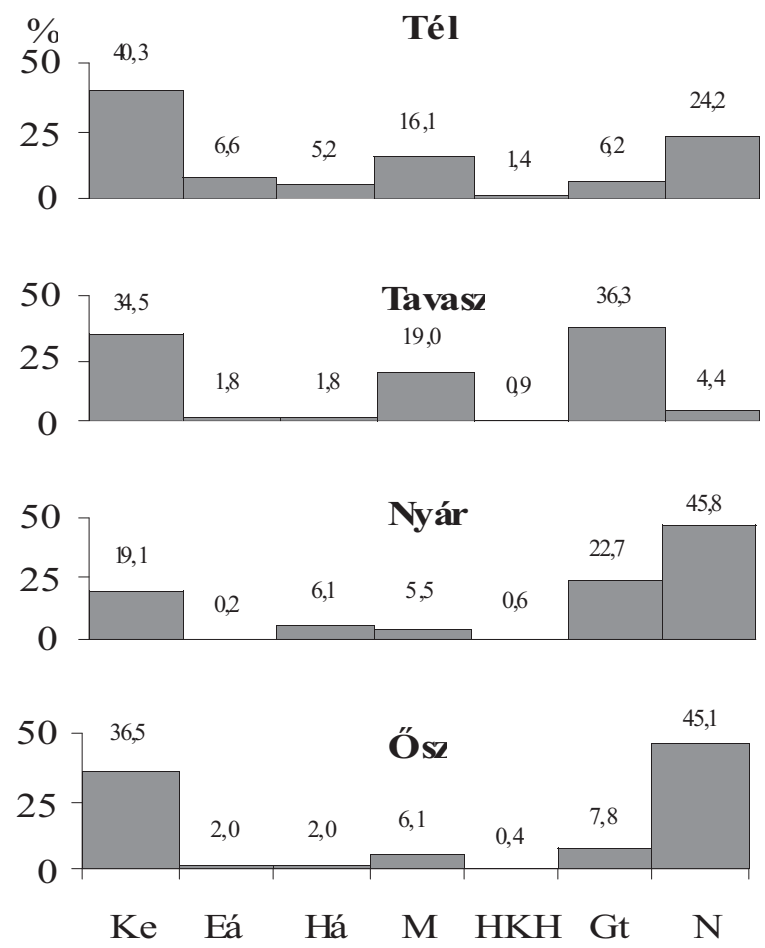

1. ábra: A nyest évszakos tápláléka a fonói halastó körzetében (1991-1997;

Lanszki és Körmendi, 1999, Lanszki et al. 1998, 1999 alapján)

$\mathrm{Ke}=$ kisemlősök, Eá = elhullott állatok (föként csülkös vad), Há = háziállatok,

$\mathrm{M}=$ madarak, HKH = hüllők, kétéltüek és halak, $\mathrm{Gt}=$ gerinctelenek, $\mathrm{N}=$ növények 


\section{1. táblázat: Mezőgazdasági és urbánus környezetben élő nyestek táplálék-összetétele}

Jelmagyarázat: $\mathrm{E} \%=$ százalékos relatív előfordulási gyakoriság; $\mathrm{B} \%$ = elfogyasztott biomassza (\%). A zsákmány súlykategóriái: 1 - 15 g alatt, 2 - 15-50 g, 3-51-100 g, 4 - 101-300 g, 5 - 300 g felett. A zsákmány jellemző előfordulási szintje (I.): t - talajszinten, valamint jellemzően talajszinten, de esetenként bokrokon, fákon is (ide sorolva az elhullott példányból, ill. állatvágásból fogyasztás); bf - bokron és fán, valamint jellemzően bokron és fán, de esetenként talajszinten is (ide sorolva az eresz alatt, illetve épületekben magasan élő egyedek fogyasztása is); v - vizes élőhelyen (vízi és vízhez kötődő). A zsákmány jellemző élőhelyi kötődése (II.): h - házhoz, ill. emberhez kötődő; vé - vadon élő; v - vegyes. + = 0,05\%-nál kisebb arányban fordult elö.

\begin{tabular}{|c|c|c|c|c|c|c|}
\hline \multirow{4}{*}{ Tápláléktaxon } & \multicolumn{3}{|c|}{ A zsákmány } & \multicolumn{3}{|c|}{ A nyest tápláléka } \\
\hline & \multirow[t]{2}{*}{ Súlya } & \multicolumn{2}{|c|}{ Élőhelye } & \multirow{3}{*}{$\begin{array}{c}\begin{array}{c}\text { Fonói halastó } \\
\text { körzetében }\end{array} \\
\text { Éves(1991-1997) } \\
\text { E\% }\end{array}$} & \multicolumn{2}{|c|}{ Fonó községben } \\
\hline & & I. & II. & & & 98) \\
\hline & \multicolumn{3}{|c|}{ (kategóriák) } & & $\mathbf{E} \%$ & $\mathbf{B} \%$ \\
\hline Kis- és közepes emlősök & & & & 29,9 & 15,5 & 28,1 \\
\hline Közönséges törpedenevér( Pipistrellus pipistrellus ) & 1 & $\mathrm{bf}$ & $\mathrm{v}$ & 0,1 & & \\
\hline Vakond( Talpa europea ) & 3 & $\mathrm{t}$ & $\mathrm{v}$ & 0,2 & & \\
\hline Mezei cickány (Crocidura leucodon ) & 1 & $\mathrm{t}$ & vé & 0,1 & & \\
\hline Cickány( Soricidae spp.) & 1 & $\mathrm{t}$ & vé & 0,6 & 0,2 & 03 \\
\hline Mókus (Sciurus vulgaris ) & 4 & bf & vé & 0,3 & & \\
\hline Nagy pele (Myoxus glis) & 4 & $\mathrm{bf}$ & vé & 0,1 & 0,2 & 1,2 \\
\hline Mogyorós pele (Muscardinus avellanarius ) & 2 & $\overline{b f}$ & vé & 0,9 & & \\
\hline Közönséges erdei egér (Apodemussylvaticus ) & 2 & $\mathrm{t}$ & vé & & 1,1 & 1,4 \\
\hline Sárganyakúerdei egér $\quad$ (Apodemusflavicollis ) & 2 & $\mathrm{t}$ & vé & 2,3 & 0,4 & 0,3 \\
\hline Pirókegér (Apodemusagrarüus $\quad$ ) & 2 & $\mathrm{t}$ & vé & 0,1 & 0,2 & 0,4 \\
\hline Erdei egér (Apodemus $\quad$ spp.) & 2 & $\mathrm{t}$ & vé & 4,4 & 1,3 & 1,4 \\
\hline $\begin{array}{ll}\text { Vándorpatkány } \quad \text { (Rattusnorvegicus } \\
\end{array}$ & 4 & $\mathrm{t}$ & $\mathrm{h}$ & 0,5 & 1,1 & 1,9 \\
\hline Házi egér (Musmusculus ) & 2 & $\mathrm{t}$ & $\mathrm{h}$ & 1,2 & 5,8 & 12,3 \\
\hline Pézsmapocok( Ondatrazibethicus & 5 & $\mathrm{v}$ & vé & 0,5 & & \\
\hline Vízipocok( Anvicolatemestris ) & 4 & $\mathrm{v}$ & vé & & 0,2 & 1,1 \\
\hline Erdei pocok (Clethrionomysglareolus & 2 & $\mathrm{t}$ & vé & 6,1 & 0,2 & 0,2 \\
\hline Földi pocok (Microtussubterraneus & 2 & $\mathrm{t}$ & $\mathrm{V}$ & 0,1 & & \\
\hline Mezei pocok (Microtusarvalis ) & 2 & $\mathrm{t}$ & vé & 9,2 & 3,0 & 6,6 \\
\hline Csalitjárópocok( Microtusagrestis & 2 & $\mathrm{t}$ & vé & 0,1 & & \\
\hline Pocok( Microtus spp.) & 2 & $\mathrm{t}$ & $\mathrm{v}$ & 0,9 & 0,2 & 0,3 \\
\hline Rágcsáló( Rodentia spp.) & 2 & $\mathrm{t}$ & $\mathrm{v}$ & 2,0 & 1,5 & 0,8 \\
\hline Mezei nyúl (Lepuseuropaeus & 5 & $\mathrm{t}$ & vé & 0,3 & & \\
\hline Elhullott állatok & & & & 2,1 & - & - \\
\hline Borz (Melesmeles ) & 5 & $\mathrm{t}$ & vé & 0,1 & & \\
\hline Vaddisznó( Susscrofa ) & 5 & $\mathrm{t}$ & vé & 0,1 & & \\
\hline Öz (Capreoluscapreolus ） & 5 & $\mathrm{t}$ & vé & 1,7 & & \\
\hline Gímszarvas( Cervuselaphus ) & 5 & $\mathrm{t}$ & vé & 0,1 & & \\
\hline Szarvasféle ( Cervidae spp.) & 5 & $\mathrm{t}$ & vé & 0,1 & & \\
\hline
\end{tabular}




\section{1. táblázat folytatása}

\begin{tabular}{|c|c|c|c|c|c|c|}
\hline \multirow{4}{*}{ Tápláléktaxon } & \multicolumn{3}{|c|}{ A zsákmány } & \multicolumn{3}{|c|}{ A nyest tápláléka } \\
\hline & \multirow[t]{2}{*}{ Súlya } & \multicolumn{2}{|c|}{ Élöhelye } & \multirow{3}{*}{$\begin{array}{c}\begin{array}{c}\text { Fonói halastó } \\
\text { körzetében }\end{array} \\
\text { Éves(1991-1997) } \\
\text { E\% }\end{array}$} & \multicolumn{2}{|c|}{ Fonóközségben } \\
\hline & & I. & II. & & & 998) \\
\hline & \multicolumn{3}{|c|}{ (kategóriák) } & & E\% & $\mathrm{B} \%$ \\
\hline Háziállatok & & & & 4,2 & 14,8 & 19,4 \\
\hline Házimacska( Feliscatus ) & 5 & $t$ & $\mathrm{v}$ & 0,1 & & \\
\hline Házinyúl & 5 & $\mathrm{t}$ & $\mathrm{h}$ & 1,6 & 0,6 & 1,0 \\
\hline Juh & 5 & $\mathrm{t}$ & $\mathrm{h}$ & 0,1 & 0,2 & 0,1 \\
\hline Kecske/szarvasmarha & 5 & $\mathrm{t}$ & $\mathrm{h}$ & 0,2 & 0,2 & 1,0 \\
\hline Sertés & 5 & $\mathrm{t}$ & $\mathrm{h}$ & & 0,4 & 0,7 \\
\hline Baromfiféle & 5 & $\mathrm{t}(\mathrm{bf})$ & $\mathrm{h}$ & 1,7 & 3,7 & 12,5 \\
\hline Tojás(baromfi) & 4 & $\mathrm{t}$ & $\mathrm{h}$ & 0,5 & 9,7 & 4,1 \\
\hline Madarak & & & & 10,2 & 19,8 & 36,8 \\
\hline Házi veréb( Passerdomesticus & 2 & bf & $\mathrm{h}$ & & 7,5 & 18,4 \\
\hline Cinege ( Parus spp.) & 1 & $\mathrm{bf}$ & $\mathrm{v}$ & & 0,9 & 2,6 \\
\hline Tengelic (Cardueliscarduelis & 1 & bf & $\mathrm{v}$ & 0,5 & 0,2 & 0,7 \\
\hline Füzike (Phylloscopus $\quad$ spp.) & 1 & bf & vé & 0,1 & & \\
\hline Kistestüénekesmadár $\quad$ (Passeriformes $\quad$ spp.) & 2 & bf & $\mathrm{v}$ & 8,9 & 10,5 & 14,1 \\
\hline Fácán( Phasiamuscolchicus ) & 5 & $\mathrm{t}$ & vé & 0,2 & & \\
\hline Balkáni gerle( Streptopeliadecaocto & 4 & bf & $\mathrm{v}$ & 0,1 & & \\
\hline Közepesméretümadár & 3 & bf & $\mathrm{v}$ & & 0,2 & 0,9 \\
\hline Tojás & 2 & $\mathrm{bf}(\mathrm{t})$ & $\mathrm{v}$ & 0,4 & $\overline{0,4}$ & 0,1 \\
\hline Hüllök+kétéltǘek & & & & $\mathbf{0 5}$ & - & - \\
\hline Vízisikló( Natrix natrix ) & 3 & $\mathrm{v}$ & $\mathrm{v}$ & 0,3 & & \\
\hline Tojás( Natrix natrix ) & 1 & $\mathrm{v}$ & $\mathrm{V}$ & 0,1 & & \\
\hline Béka ( Amura spp.) & 2 & $\mathrm{t}$ & $\mathrm{v}$ & 0,1 & & \\
\hline Halak & 4 & $\mathrm{v}$ & vé & $\mathbf{0 3 3}$ & - & - \\
\hline Gerinctelenek & & & & 19,2 & 18,9 & 0,5 \\
\hline Szöcske( Tettigonidea spp.) & 1 & $\mathrm{t}$ & $\mathrm{v}$ & 0,1 & & \\
\hline Lótücsök( Gryllotalpagyllotalpa ) & 1 & $\mathrm{t}$ & $\mathrm{v}$ & 0,3 & 0,6 & + \\
\hline Aranypettyesfutrinka ( Carabushortensis ) & 1 & $\mathrm{t}$ & vé & 2,9 & & \\
\hline Ragyás/rezesfutrinka $\quad$ (Carabus $\quad$ spp.) & 1 & $\mathrm{t}$ & vé & 3,2 & & \\
\hline Kékfutrinka ( Carabusviolaceus ) & 1 & $\mathrm{t}$ & vé & 1,1 & & \\
\hline Börfutrinka( Carabuscoriaceus ) & 1 & $\mathrm{t}$ & vé & 0,3 & & \\
\hline Aranyosbábrabló( Carabussycophanta & 1 & $\mathrm{t}$ & vé & 0,4 & & \\
\hline Gyászfutó( Pterostichus spp.) & 1 & $\mathrm{t}$ & $\mathrm{v}$ & & 2,4 & + \\
\hline Fémfutó( Harpalus spp.) & 1 & $\mathrm{t}$ & $\mathrm{v}$ & & 0,4 & + \\
\hline Futóbogár (Carabidae spp.) & 1 & $\mathrm{t}$ & $\mathrm{v}$ & 1,6 & $\overline{0,4}$ & + \\
\hline Pattanóbogár( Elateridae spp.) & 1 & $\mathrm{t}$ & $\mathrm{v}$ & 0,2 & & \\
\hline Szarvasbogár( Lucamuscervus ) & 1 & $\mathrm{t}$ & vé & 1,7 & & \\
\hline Tavaszi ganéjtúró( Geotrupesvernalis & 1 & $\mathrm{t}$ & vé & 0,1 & & \\
\hline Erdei-/közönségesgalacsinhajtó( $\quad$ Geotrupes $\quad$ spp.) & 1 & $\mathrm{t}$ & vé & 0,3 & & \\
\hline Galacsinhajtó( Scarabeidae spp.) & 1 & $\mathrm{t}$ & vé & 0,1 & 0,2 & + \\
\hline Aranyos rózsabogár( Cetonia aurata & 1 & $\mathrm{t}$ & $\mathrm{v}$ & 0,3 & & \\
\hline Rózsabogár( Cetonia spp.) & 1 & $\mathrm{t}$ & $\mathrm{v}$ & & 0,9 & + \\
\hline Májusi cserebogár $\quad$ (Melolonthamelolontha & 1 & $\mathrm{t}$ & $\mathrm{v}$ & 0,3 & & \\
\hline Cserebogár( Melolonthidae spp.) & 1 & $\mathrm{t}$ & $\mathrm{v}$ & 0,1 & 1,3 & + \\
\hline
\end{tabular}




\section{1. táblázat folytatása}

\begin{tabular}{|c|c|c|c|c|c|c|}
\hline \multirow{4}{*}{ Tápláléktaxon } & \multicolumn{3}{|c|}{ A zsákmány } & \multicolumn{3}{|c|}{ A nyest tápláléka } \\
\hline & \multirow[t]{2}{*}{ Súlya } & \multicolumn{2}{|c|}{ Élöhelye } & \multirow{3}{*}{$\begin{array}{c}\begin{array}{c}\text { Fonói halastó } \\
\text { körzetében }\end{array} \\
\text { Éves(1991-1997) } \\
\text { E\% }\end{array}$} & \multicolumn{2}{|c|}{ Fonóközségben } \\
\hline & & I. & II. & & \multicolumn{2}{|c|}{ Éves(1998) } \\
\hline & \multicolumn{3}{|c|}{ (kategóriák) } & & $\mathbf{E} \%$ & B\% \\
\hline Bogár( Coleoptera spp.) & 1 & $\mathrm{t}$ & $\mathrm{v}$ & 0,3 & 2,8 & + \\
\hline Bogár( Coleoptera spp.) lárva & 1 & $\mathrm{t}$ & $\mathrm{v}$ & & 0,6 & + \\
\hline Kékfadongó( Xylocopavalga ) & 1 & $\mathrm{t}$ & $\mathrm{v}$ & & 0,4 & + \\
\hline Német darázs( Paravespulagermanica & 1 & $\mathrm{t}$ & $\mathrm{v}$ & 0,1 & & \\
\hline $\begin{array}{ll}\text { Padlásdarázs } & \text { (Polistesnimfa }\end{array}$ & 1 & $\mathrm{t}$ & $\bar{h}$ & 0,1 & 13 & + \\
\hline Lódarázs( Vespacrabro ) & 1 & $\mathrm{t}$ & $\mathrm{v}$ & 0,1 & 0,4 & + \\
\hline Darázs( Vespidae spp.) & 1 & $\mathrm{t}$ & $\overline{\mathrm{v}}$ & 0,1 & 4,5 & 0,1 \\
\hline Darázs( Vespidae spp) lárva & 1 & $\mathrm{t}$ & $\mathrm{v}$ & & 0,2 & + \\
\hline Háziméh( Apismellifera ) & 1 & $\mathrm{t}$ & $\mathrm{v}$ & & 0,2 & + \\
\hline Erdei vöröshangya ( Formicanffa ) & 1 & $\mathrm{t}$ & vé & 0,1 & & \\
\hline Hártyászárnyú $\quad$ (Hymenoptera $\quad$ spp.) & 1 & $\mathrm{t}$ & $\overline{\mathrm{v}}$ & 0,4 & & \\
\hline Rovar( Insecta spp.) & 1 & $\mathrm{t}$ & $\mathrm{v}$ & 4,7 & 1,3 & 0,1 \\
\hline Rovar( Insecta spp.)lárva & 1 & $\mathrm{t}$ & $\mathrm{v}$ & & 0,4 & + \\
\hline Csiga ( Gastropoda & 1 & $\mathrm{t}$ & $\overline{\mathrm{v}}$ & 0,3 & $\overline{0,4}$ & + \\
\hline Növények & & & & 33,6 & 31,0 & 15,2 \\
\hline Szőlö( Vitisvinifera ) & & & & 2,7 & 3,7 & 1 \\
\hline Cseresznye (Cerasusavium ) & & & & 10,1 & 4,3 & 5,3 \\
\hline Meggy( Cerasusvulgaris ) & & & & 1,7 & 1,5 & 0,9 \\
\hline Húsossom( Comusmas ) & & & & 1,0 & & \\
\hline Szamóca/málna ( Fragaria/Rubus spp.) & & & & 2,7 & 1,1 & + \\
\hline Szeder( Rubusspp. ) & & & & 2,3 & 0,4 & + \\
\hline Eper( Monus spp.) & & & & & 0,2 & + \\
\hline Ribizli ( Ribes spp.) & & & & & 0,2 & + \\
\hline Csipkebogyó( Rosa canina ) & & & & 1,8 & 0,4 & 0,2 \\
\hline Kökény( Pnumusspinosa ) & & & & 4,9 & 0,4 & 0,4 \\
\hline Szilva ( Prumusdomestica ) & & & & 1,7 & 1,7 & 2,2 \\
\hline Alma ( Malus spp.) & & & & & 1,5 & 0,7 \\
\hline Körte ( Pynus spp.) & & & & & 1,1 & 0,3 \\
\hline Gyümölcs,meghatározhatatlan & & & & 1,0 & 6,7 & 1,8 \\
\hline Búza ( Triticum aestivum ) & & & & 0,1 & 0,2 & + \\
\hline Árpa ( Hordeum spp.) & & & & & 0,4 & + \\
\hline Kukorica ( Zeamays ) & & & & 0,4 & 0,4 & 0,1 \\
\hline Napraforgó( Helianthusanmus ) & & & & 0,2 & 1,9 & 0,7 \\
\hline Borostyán( Hederahelix ) & & & & 0,3 & & \\
\hline Mag & & & & 0,5 & 0,4 & 0,1 \\
\hline Levél & & & & 0,3 & & \\
\hline Pázsitfüfélék( Gramineae spp.) & & & & 1,8 & 3,9 & 1,0 \\
\hline Kender( Cannabissativa ) & & & & & 0,2 & 0,3 \\
\hline Paprika & & & & & 0,2 & + \\
\hline Virág & & & & 0,1 & & \\
\hline Gyékény/sás( Typha/Carex spp.) & & & & 0,1 & & \\
\hline n(vizsgált hullatékokszáma) & & & & 572 & & \\
\hline t/n(egyhullatékra jutótáplálékalkotók száma) & & & & 2,0 & & \\
\hline B(niche szélesség) & & & & 5,0 & 4,89 & 4,27 \\
\hline
\end{tabular}


nyuk azt jelzi, hogy nem jellemző táplálékai a nyestnek.

A gerinctelenek előfordulási gyakorisága mindkét esetben magas (19\%) és szinte teljes mértékben azonos volt (1. táblázat). A ragadozó emlősök táplálékában azonban a gerinctelenek biomasszája elenyésző a relatív gyakorisági adatokhoz képest (részletesebben JEDRZEJEWSKA és JEDRZEJEWSKI 1998), amire példa az urbánus nyestek tápláléka, ahol az előfordulási gyakorisági, valamint a biomassza adatok (18,9, ill. 0,5\%) közötti különbség 38-szoros. Faunisztikai szempontból érdekes, hogy a mezőgazdasági környezetben élő nyestek rovartápláléka gazdagabb volt, futóbogár fajok, valamint szarvasbogár szerepelt nagy arányban. Ugyanakkor a lakott területen élő nyestek táplálékában föként darazsak voltak találhatók és ezzel együtt feltételezhető a mézfogyasztás (SERAFINI és LOVARI 1993) is.

A teljes táplálék lista alapján, mindkét nyest populáció táplálékában előfordulási gyakoriság szerint a növények domináltak (1. táblázat). Ezek közül a különböző gyümölcsök játszották a fő szerepet. Mindkét esetben a cseresznye volt a legfontosabb, emellett a halastó körzetében élő nyestek jelentős arányban vadon termő gyümölcsöket (som, szeder, kökény), a lakott területen élők pedig szőlőt fogyasztottak.

A vizsgált nyestek széles táplálkozási spektrumát jelzi az 53 préda és a 17 növény taxon előfordulása a halastó körzetében élő egyedek táplálékéban. A lakott területen élő nyesteknél 30 különböző zsákmányállatot és 19 növény taxont lehetett elkülöníteni. A táplálkozási niche-szélesség (mely a táplálék változatosságának és a taxonok egymáshoz viszonyított arányainak mérőszáma) mindkét esetben magas volt $(5,00$, ill. 4,89). Egyetlen táplálék taxon sem szerepelt 40\%-os arány fölött.

2. táblázat: Emészthetetlen anyagok előfordulása mezőgazdasági és urbánus környezetben élő élő nyestek táplálékában

\begin{tabular}{|l|c|c|}
\hline \multirow{2}{*}{\multicolumn{1}{|c|}{ Anyag típusa }} & Fonö halasto Korzeteben & Fono kösegben \\
\cline { 2 - 3 } & \multicolumn{2}{|c|}{ Elöfordulási esetek } \\
\hline Nylon/müanyag darabka & 1 & 1 \\
\hline Horgászzsinór & & 2 \\
\hline Múanyag kötözözsinór & & 2 \\
\hline Gumidarab & & 8 \\
\hline Kondom & & 1 \\
\hline Szalámihéj & & 1 \\
\hline Tejeszacskó & & 1 \\
\hline Mübőr & & 5 \\
\hline Alumínium fólia & & 1 \\
\hline Üvegdarab & & 2 \\
\hline Céma & & 3 \\
\hline Papír & & 2 \\
\hline Tégladarab & & 1 \\
\hline Kályha salak & & 4 \\
\hline Kavics & & \\
\hline
\end{tabular}




\section{Emészthetetlen anyagok a táplálékban}

Az egyéb komponensek (szervetlen, illetve emészthetetlen anyagok) a lakott területen élő nyestek táplálékában lényegesen nagyobb gyakorisággal $\chi^{2}=67,52, \mathrm{df}=1, \mathrm{p}<0,001$ ) fordultak elö, mint a halastó körzetében élőknél. Ezeket az anyagokat feltételezhetően, zömmel szemétdombokon fogyaszthatták. Az elfogyasztott szemét igen változatos képet mutatott, leggyakoribbak a gumiféleségek voltak (2. táblázat).

\section{Táplálékválasztás a préda súlya és jellemző előfordulása szerint}

A préda fajok súlya alapján a két nyestpopuláció tápláléka szignifikánsan különbözött $\left.\chi^{2}=74,61, \mathrm{df}=4, \mathrm{p}<0,001\right)$. Jellemzően a 15 és az 50 gramm közötti súlykategóriába eső prédát fogyasztották, azonban az urbánus nyestek étlapján az $50 \mathrm{~g}$ feletti préda is jelentős volt (2. ábra). Különbözött a két a nyestpopuláció a fogyasztott zsákmány fajok jellemző előfordulási szintje szerint is $\left.\chi^{2}=22,12, \mathrm{df}=2, \mathrm{p}<0,001\right)$. A nyestek jellemzően a talajszint közelében élő prédát fogyasztották. Azonban a mezőgazdasági környezetben élő nyestek a talajszinten mozgó zsákmányt, míg a lakott területen élő nyestek a bokrokon, ereszek alatt, vagy a fák lombkorona szintjén élő állatokat választották nagyobb arányban (3. ábra). Lényeges eltérés volt tapasztalható a két nyest csoport között a préda fajok jellemző előfordulási helye (kötődése) szerint is $\chi^{2}=255,34, \mathrm{df}=2, \mathrm{p}<0,001$ ). Az emberi településen kívül élő nyestek a vadon élő préda fajokat, a lakott területen élö nyestek pedig az emberhez kötődő fajokat fogyasztották nagyobb arányban (4. ábra).

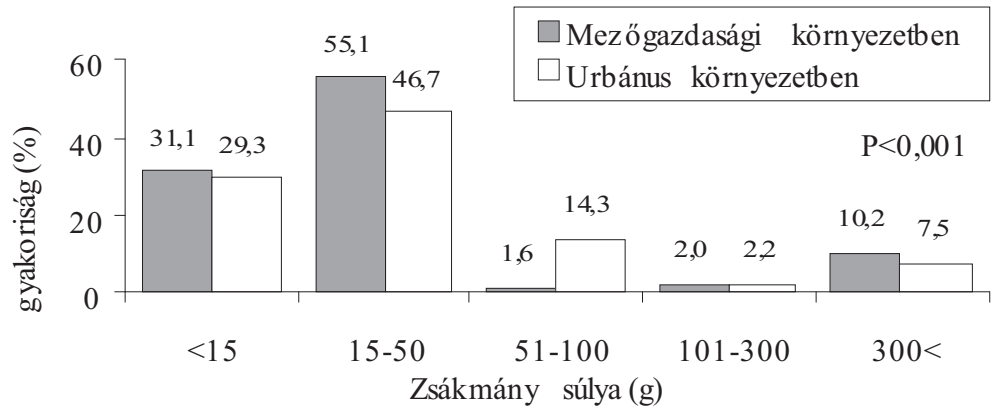

2. ábra: Mezőgazdasági és urbánus környezetben élő nyestek prédaválasztása a zsákmány súlya alapján

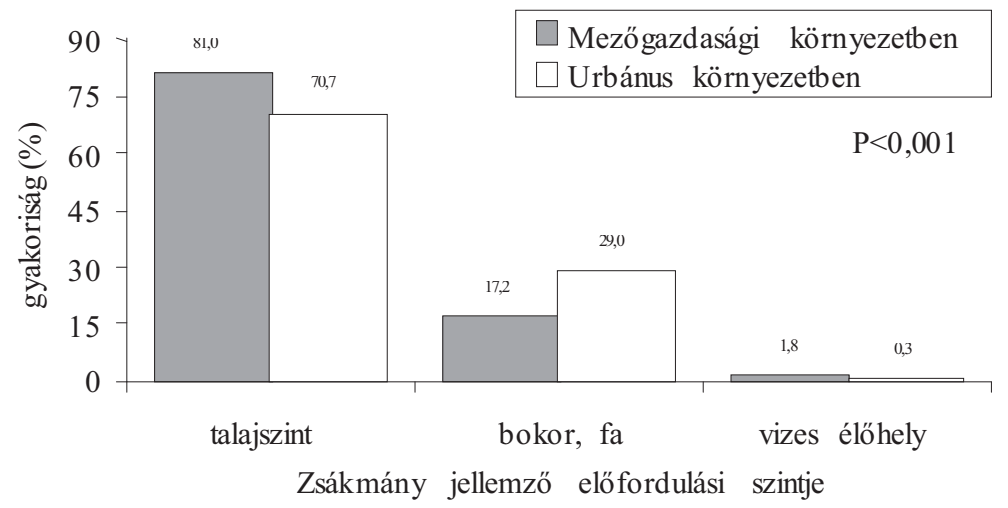

3. ábra: Mezőgazdasági és urbánus környezetben élő nyestek prédaválasztása a zsákmány jellemző előfordulási szintje alapján 


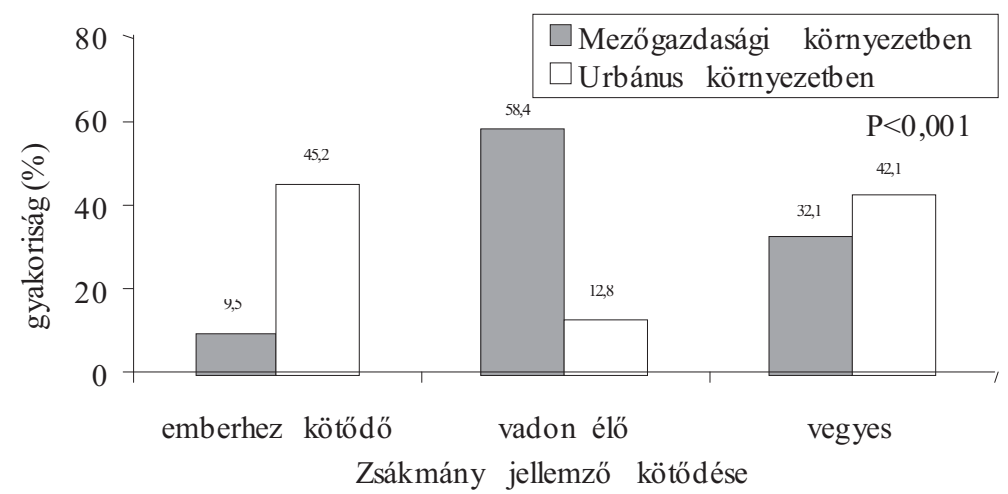

\section{4. ábra: Mezőgazdasági és urbánus környezetben élő nyestek prédaválasztása a zsákmány élőhelyi kötődése alapján}

\section{Következtetések}

A vizsgálat alapján megállapítható, hogy az emberi településen kívül élő és az urbánus nyestek táplálkozási niche-átfedése nagymértékü, mégis a táplálék-összetételük taxonómiai szempontból különbözik. Ez azt jelzi, hogy a jelentős fajon belüli kompetíció ellenére táplálkozási niche-szegregálódás valósul meg. Az alapvetően eltérő élőhelyhez kötődő nyestek egyaránt széles táplálékbázist hasznosítanak, a tartós egymás mellett élés érdekében a forrásokat felosztják térben és időben. Ezt a feltételezést támasztják alá az alábbi vizsgálati eredmények:

1) függetlenül a jellemző élőhelyüktől, a nyestek táplálkozási niche-e széles, a táplálékforrások igen széles körét képesek hasznosítani; a szemétben való keresésben lényeges különbség tapasztalható,

2) bár jellemzően 15 és 50 g közötti súlyú prédát ejtenek, az urbánus nyestek a nagyobb súlyú prédát gyakrabban részesítik előnyben, mint a mezőgazdasági környezetben élők,

3) az urbánus nyestek több bokor, illetve fa lombkorona szintjén élő és kevesebb talajszint közelében élő prédát fogyasztanak, mint a mezőgazdasági környezetben élők,

4) az urbánus nyestek nagyobb arányban fogyasztanak emberhez kötődő és kisebb arányban vadon (lakott területen kívül) élő prédát. A háziállat fogyasztásban lényeges különbség tapasztalható a két nyestpopuláció között.

A nyestek opportunista predációját (GosZCZYNSKi 1986, MitCHELL-JONES et al. 1999) támasztja alá a jelen tanulmányban vizsgált nyestek széles táplálékspektruma és viszonylag kiegyenlített táplálék-összetétele. A mezőgazdasági környezetben élő egyedek étlapján 70, az urbánus nyesteknél 49 különböző táplálék taxon fordult elő. Ezek az adatok hasonlóan magasak a Boronka-melléki Tájvédelmi Körzetben, lombhullató erdővel körülvett halastavak körzetében, természetes környezetben élő szárazföldi ragadozóknál tapasztaltakhoz, pl. a nyusztnál 45, a vörösrókánál 51 és a borznál 40 taxon fordult elő (LANSZKI és KÖRMENDI 2000).

A különböző nyestpopulációk közötti kapcsolatok meglétét a fontosabb táplálékok közös hasznosítása révén (is) lehet mérni. A nyesttel rokon közönséges görényen végzett megfigyelés szerint a kifejlett egyedek táplálékpreferenciáját alapvetően befolyásolja, hogy 2-3 hónapos életkorig az anya milyen táplálékot (tulajdonképp a préda szaga a 
meghatározó) hordott kölykei számára (összefoglalta: BLANDFORD 1987). Feltételezhetően ez a tanulási folyamat a nyestre is érvényes lehet, legalábbis ami az élőhely (fészekhelyek) megválasztását illeti

A nyestek étlapján előfordulási gyakoriság alapján a növények, ezek közül is a gyümölcsök a legjelentősebbek. A gyümölcsök vitamin és szénhidrát forrásként fontosak (PANDOLFI et al. 1996), bár a Martes genus esetében a szervezet téli zsírraktár képzése nem olyan jelentős, mint például a borznál. Ez is hozzájárul a nyestek téli folyamatos aktivitásához (pl. ZALEWSKI 2000). A nyestek nyáron főként gyümölcsfogyasztás érdekében járnak be lakott területre, emellett a nyári párosodási időszakban hosszabb utat tesznek meg, miközben háziállatokat, illetve állatvágási maradékokat (sertés, juh, kecske, baromfi) is fogyasztanak. Télen is jelentős a növények fogyasztása (DELIBES 1978, PANDOLFI et al 1996) a padlásokon aszalt szőlőt is megdézsmálják (ez azonban a rágcsálókra is jellemző). Fontos szerepet töltenek be a magvak szétterjesztésében (HERRERA 1989).

A mủanyag és gumi alapanyagú termékek (ill. szemét) fogyasztása összefügg a nyestek kíváncsi és játékos természetével, ugyanis elöszeretettel rágcsálnak puha anyagot (főként a kölykök). Ez játszhat közre az autók kábeleinek és más műanyag, vagy gumi tartozékok megrongálásában is (SEKNACK 1993). Ilyen jellegű anyagok az emberi településektől távol, zárt erdőkben élő közeli rokon faj, a nyuszt táplálékában nem fordulnak elő (még a vörösrókánál is ritkán), melyek háziállatot sem fogyasztanak (LANSZKI és KÖRMENDI 2000).

A lakott területen élő nyestek nagyobb tápláléksűrűségű élőhelyen élnek, a kisebb territórium is elegendő táplálékot képes biztosítani. A bejárható kisebb távolságokkal, és a rendelkezésre álló táplálékforrás minőségével (pl. szárnyas háziállatok) függhet össze, hogy a nagyobb súlyú (51-100 g) zsákmányállatotot is probléma nélkül vihetik szájukban a táplálkozó helyre, vagy a fészekbe. A lakott területen kívül élő nyestek táplálékában a kisemlősök a legjelentősebb prédák a jelen és más vizsgálatokban is (DELIBES 1978, RASMUSSEN és MAdSEN 1985, GoszCZYNSKi 1986, Serafini és Lovari 1993), az urbánus nyestek táplálékában pedig a madarak, főként galambok (HoLISOVÁ és OBRTEL 1982, Rasmussen és MAdSen 1985, LuCERINi és CREMA 1993, Sidorovich 1997, TóTHАРÁTHY 1998). Az 50 g feletti súlykategóriába tartozó fajok között jelentős arányba szerepelnek háziállatok.

A kompetítor fajok jelenléte is befolyásolja a nyestek előfordulását, állománysűrűségét és táplálékválasztását. Emberi településeken a nyestnek lényegesen kevesebb kompetítorral kell a forrásokat felosztani (HoLISOvÁ és OBRTEL 1982, LUCERINI és CREMA 1993). A nyest urbanizálódó viselkedése nagy hasonlóságot mutat a vörösrókához (pl. DONCASTER et al. 1990, MitCHELL-JONES et al. 1999), a két faj között a természetes környezetben jelentős kompetíció tapasztalható (SERAFINI és LOVARI 1993, BRANGI 1995, LANSZKI et al. 1999). A nyesthez alkatilag is közel álló rokon nyuszt élőhely igénye és tápláléka általában lényegesen eltér a nyesttől (pl. MitCHELL-JONES et al. 1999), azonban együttesen is előfordulhatnak (GoszCZYNSKI 1977, PEDRINI et al. 1995). A nyest, a nyuszttal összehasonlítva ritkábban mászik fára, bár fészkét általában magasban (ház padlásán, odvas fában) készíti. Vadászatának jellemző szintje a talaj és az alacsony tereptárgyak. A nyesttel való találkozást, a kompetítornak tekinthető házimacskák általában elkerülik, esetenként azonban előfordul, hogy a nyestek, - valószínüleg - kölyökmacskákat ejtenek zsákmányul (TóTH-AРÁTHY, 1998).

A vizsgálat alátámasztja az emberi településen élő nyestek jelentős házi egér és vándorpatkány fogyasztását. Korlátozzák a kártékony rágcsálók nagymértékű elszaporodását, aminek közegészségügyi és gazdasági jelentősége egyaránt vitathatatlan. Ezek a rágcsálók a lakott területen kívül élő nyestek táplálékában is szerepelnek, de kisebb arányban.

Nagy különbség tapasztalható háziállatok fogyasztása tekintetében a jellemzően lakott területtől távol élő és az emberi településen élő nyestek között. Az utóbbiak háromszo- 
ros mennyiségben fogyasztanak háziállatot, melyek közül legjelentősebbek a baromfifélék. A baromfifélék biomassza szerinti aránya hasonló a kistestű madarakéhoz, vagy a házi egéréhez. A háziállatok előfordulása a ragadozók táplálékában a téli állatvágásokkal (JENSEN és SEQUEIRA 1978), valamint a halastó közvetlen körzetében, a téli relatíve szükös táplálékforrással magyarázható. A nyers sertésvágási maradványok potenciális táplálékforrást jelentenek, azonban a füstölt, vagy pácolt termékeket nem a nyestek dézsmálják meg, hanem a rágcsálók (jellegzetes a rágásnyom). Ezt fogságban felnevelt nyesten végzett megfigyeléssel egyértelműen bizonyítani lehetett. A füszeres kolbászt, pácolt sonkát, vagy a tartósítószerekkel kezelt beföttet a nyest nem fogyasztja el (Szerző nem publikált megfigyelése). Problémát jelent, hogy „nyestmentes” állattartó épület kialakítása szinte lehetetlen, gyakran még a lakóépületek padlástere is költségesen zárható le. Megoldást jelenthet hóban, vagy eső után a nyomok, feljáróhelyek (kerítés, háztetőhöz közel érő faág, létra, alacsony épületek) megfigyelése, ezáltal a bebúvó nyílások feltérképezése, éjszakai fény-, vagy hangriasztás alkalmazása (lámpával, illetve rádióval), majd a nyestek távollétében a nyílások lezárása.

Az urbanizálódott és a lakott területen kívül élő nyest populációk tényleges közös territórium használatára és az állományok nagyságának vizsgálatára költségesebb, közvetlen módszerek alkalmazása (pl. a radio-telemetria: SEILER et al. 1994, PosiLlico et al. 1995, genetikai vizsgálat: pl. DALLAS et al. 1999, 2000) szolgálhat további értékes adatokkal. Ezek mellett azonban a jelen vizsgálatban szereplő egyszerü közvetett módszerrel is új eredmények nyerhetők a faj életmódjáról. A vizsgálat nem adhat választ arra, hogy a természetes környezetben született nyestek életük során urbánus nyestté válhatnak-e, illetve fordítva, azonban az alapvetően különböző élőhelyhez kötődő nyestek egyaránt széles és részben közös táplálékforrásokat hasznosítanak. A különböző nyestpopulációk, az egymás mellett élés érdekében a forrásokat felosztják térben és időben. A mezőgazdasági és az urbánus környezetben élő nyestek egyaránt fogyasztanak emberi településekhez kötődő táplálékot, pl. háziállatokat és kertben termő gyümölcsöket, valamint vadon élö állatokat is. Ezek az eredmények azt jelzik, hogy a nyest populációk egyedei nem különülnek el élesen térben, legfeljebb időszakosan.

\section{Köszönetnyilvánítás}

Köszönöm Körmendi Sándornak a kézirat összeállításakor adott hasznos tanácsait. A kutatást az OTKA (F 023057) támogatta.

\section{Irodalom}

Bertolino, S., Dore, B. 1995: Food habits of the stone marten Martes foina in „La Mandria” Regional Park (Piedmont Region, North-western Italy). Hystrix, 7: 105-109.

Blandford, P.R.S. 1987: Biology of the Polecat Mustela putorius: a literature review. Mammal Rev. 17: 155198.

BRANGI, A. 1995: Seasonal changes of trophic niche overlap in the stone marten (Martes foina) and the red fox (Vulpes vulpes) in a mountainous area of the Northern Appenines (Italy). Hystrix, 7: 113-118.

Brown, R., Ferguson, J., Lawrence, M., Lees, D. 1993: Federn, Spuren und Zeichen der Vögel Europas: Ein Feldführer. Aula- verlag Wiesbaden

Clevenger, A.P. 1993: Pine marten (Martes martes Linné, 1758) comparative feeding ecology in an island and mainland population of Spain. Z. Säugetierkunde, 58: 212-224. 
Dallas, J.F., Bacon, P.J., Carss, D.N., Conroy, J.W.H., Green, R., JefFeries, D.J., KruUk, H., Marshall, F., Piertney, S.B., RACEY, P.A., 1999: Genetic diversity in the Eurasian Otter, Lutra lutra, in Scotland. Evidence from Microsatellite polymorphism. Biological Journal of the Linnean Society, 68(1-2): 73-86.

Dallas, J.F., Carss, D.N., Marshall, F., Koepfli, K.P., Kruuk, H., Piertney, S.B., Bacon, P.J. 2000: Sex identification of the Eurasian otter Lutra lutra by PCR typing of spraints. Conservation Genetics, 1: 181183.

Debrot, S., Fivaz, G., Mermod C, Weber, J.-M. 1982: Atlas des poils des mammiferes d'Europe. Institut de Zoologie, Neuchatel.

Dely, O.Gy. 1983: Hüllők-Reptilia. Magyarország Állatvilága XX. kötet, Akadémiai Kiadó, Budapest

DeLIBES, M. 1978: Feeding habits of the Stone Marten, Martes foina (Erxleben, 1777), in northern Burgos, Spain. Z. Säugetierkunde, 43: 282-288.

Doncaster C.P., Dickman, C.R., Macdonald, D.W. 1990: Feeding ecology of red foxes (Vulpes vulpes) in the city of Oxford, England. J. Mamm. 71: 188-194.

Gittleman, J.L. 1985: Carnivore body size: ecological and taxonomic correlates. Oecologia, 67: 540-554.

GoszCZYNSKI, J. 1977: Connections between predatory birds and mammals and their prey. Acta Theriologica, 22: $399-430$

GoszCZYNSKI, J. 1986: Diet of foxes and martens in central Poland. Acta Theriologica 31: 491-506.

GöRner, M., Hackethal, H. 1987: Säugetiere Europas. Neumann Verlag Leipzig- Radebeul

Green, S.B., Salkind, N.J., Akey, T.M. 1997: Using SPSS for Windows: analyzing and understanding data. Prentice Hall, New Jersey

HolisovÁ, V., Obrtel, R. 1982: Scat analytical data on the diet of urban stone martens, Martes foina (Mustelidae, Mammalia). Folia Zoologica, 31: 21-30.

Herrera, C.M. 1989. Frugivory and seed dispesal by carnivorous mammals, and associated fruit characteristics, in undisturbed Mediterranean habitats. Oikos, 55: 250-262.

JedrzejewsKa, B., Jedrzejewski, W. 1998: Predation in vertebrate communities. The Bialowieza Primeval Forest as a Case Study. Springer-Verlag, Berlin Heildelberg, New York

Jensen B., Sequeira D.M. 1978: The diet of the red fox (Vulpes vulpes L.) in Denmark. Danish Review of Game Biology 10: -16.

Krebs, C.J. 1989: Ecological methodology. Harper Collins Publishers, New York, 372-374.

LANSZKI J. 1992: A nyestek táplálkozásáról. Nimród, 1: 4-7.

LANSZKi J., KöRmENDi S., HANCZ Cs., ZALEWSKi A. 1998: Effects of habitat changes on the feeding habits and trophic niche overlap of a Carnivora community in Hungary. Euro-American Mammal Congress, Santiago de Compostela, p. 331-332.

LANSZKI J., KÖRMENDI S. 1999: Ragadozó emlős életközösség táplálékösszetétele mezőgazdasági élőhelyen, Somogy megyében. Természetvédelmi Közlemények, 8: 121-136.

LANSZKi J., Körmendi S., Hancz Cs., Zalewski A. 1999: Feeding habits and trophic niche overlap in a Carnivora community of Hungary. Acta Theriologica, 44: 429-442.

LANSZKi J., KÖRMENDI S. 2000: Diet of a Carnivora community living at Boronka Nature Conservation Area, in Somogy county. Somogyi Múzeumok Közleményei, 375-382.

LodE, T. 1994: Feeding habits of the Stone marten Martes foina and environmental factors in western France. Z. Säugetierkunde, 59: 189-191.

LuCherini, M., CREMA, G. 1993: Diet of urban stone martens in Italy. Mammalia, 57: 274-277.

Macdonald, D.W. 1980: Patterns of scent marking with urine and faeces amongst carnivore communities. Symp. Zool. Soc. Lond., 45: 107-139.

Madsen, A.B., Rasmussen, A.M. 1985: Reproduction in the stone marten Martes foina in Denmark. Natura Jutlandica, 9: 145-148.

Martinoli, A., Preatoni, D.G. 1995: Food habits of the stone marten (Martes foina) in the Upper Aveto Valley (Northern Appanines, Italy). Hystrix, 7: 137-142.

Mitchell-Jones, A.J., Amori, G., Bogdanowicz, W., Krystufek, B., Reijnders, P.J.H., Stubbe, M., Thissen, J.B.M., Vohralík, V., ZiMA, J. 1999: The atlas of European mammals. T\&AD Poyser Ltd., London, $342-$ 343

MóczÁR, L. 1969: Állathatározó I-II. kötet. Tankönyvkiadó, Budapest.

PAunOvic, M. 1990: Vodozemci iz proslosti I sadasnjosti Odredivanje skeletnih dijelova. (Kétéltű határozó csonttani bélyegek alapján), Zagreb.

Pandolfi, M., Marinis de, A.M., Petrov, I. 1996: Fruits as a winter feeding resource in the diet of Stone marten (Martes foina) in east-central Italy. Z. Säugetierkunde, 61: 215-220.

Pedrini, P., Prigioni, C., Volcan, G. 1995: Use of trophic resources and habitats by the genus Martes in Adamello-Brenta Park (Central Italian Alps). Hystrix, 7: 127-135. 
Posillico, M., Serafini, P., Lovari, S. 1995: Activity patterns of the stone marten Martes foina Erxleben, 1777 , in relation to some environmental factors. Hystrix, 7: 79-97.

Rasmussen A.M., Madsen, A.B. 1985: The diet of the stone marten Martes foina in Denmark. Natura Jutlandica, 8: 141-144.

SchmidT, E. 1967: Bagolyköpet vizsgálatok. A Magyar Madártani Intézet kiadványa, Budapest

SEKNACK, S. 1990: Autónyest. Vadvilág válogatás, 7: 28-29.

SEILER, A., KRÜGER, H.H., Festetics, A. 1994: Reaction of a male Stone marten (Martes foina Erxleben, 1777) to foreign faeces within its territory: a field experiment. Z. Säugetierkunde, 59: 58-60.

SERAFInI, P., LovAri, S. 1993: Food habits and trophic niche overlap of the red fox and the stone marten in a Mediterranean rural area. Acta Theriologica, 38 (3) 233-244.

Sidorovich, V. 1997: Mustelids in Belarus. Minsk: Zolotoy uley publisher, 263 pp.

TeERINK, B.J. 1991: Hair of West-European mammals. Cambridge University Press, Cambridge

Tester, U. 1986: Vergleichende Nahrungsuntersuchung beim Steinmarder Martes foina (Erxleben, 1777) in grossstädtischem und ländlichem Habitat. Säugetierkundliche Mitteilungen, 33: 37-52.

Tóth АрÁthy, M. 1998: Data to the diet of the urban Stone marten (Martes foina Erxleben) in Budapest. Opusc. Zool. Budapest, XXXI: 113-118.

UjHeLYI, P. 1989: A magyarországi vadonélő emlősállatok határozója. (Küllemi és csonttani bélyegek alapján) A Magyar Madártani Egyesület kiadványa, Budapest

ZALEWSKI, A. 2000: Factors affecting the duration of activity by pine martens (Martes martes) in the Bialowieza National Park, Poland. J. Zool., Lond. 251: 439-447. 


\title{
Comparative study on feeding habits of the stone marten (Martes foina Erxl.) in rural and urban environments
}

\begin{abstract}
JÓZSEF LANSZKI
Feeding habits of stone martens living outside of a settlement (district of Fonó Fish Pond, rural habitats) and urban environment (village name Fonó) was investigated by scat analysis ( $\mathrm{n}=572$ and 151, resp.). The trophic niche overlap between the two populations of stone martens was $78,5 \%$, but the diet composition differed significantly in taxonomical point of view. The dominant food of every two stone martens' population were plants (mainly fruits; 33,6 and 31,0\%, resp., relative frequency data). The main preys were small mammals $(19,9 \%$, mainly common vole) for martens living outside of the settlement and birds (19,8\%, mainly sparrow) for the urban ones. The ratio of consumed domestic animals (4,2 and 14,8\% resp., mainly poultry) in the diet of the stone marten populations differed significantly. In the diet of stone martens living on rural habitats, garbage occurred rarely; its prey was more frequently smaller and lived on ground level, characteristically far from human environment, compare to diet of urban stone martens.
\end{abstract}

\author{
Author's address: \\ Dr. József LANSZKI \\ University of Kaposvár \\ Faculty of Animal Science \\ H-7401. Kaposvár \\ P.O. Box 16 \\ HUNGARY
}

